\title{
IMPLEMENTATION OF BLENDED LEARNING FOR EARLY CHILDREN IN KINDERGARTEN BINA KEBAJIKAN
}

\author{
Luli Andriany and Rita Aryani \\ Pancasakti University \\ E-mail: Iuliandriany900@gmail.com, rita.ar17@yahoo.com
}

\begin{tabular}{lll}
\hline ARTICLE INFO ABSTRACT \\
\hline Received:
\end{tabular}

July, 24th 2021

Revised: caused changes in various aspects of life, one of which is the

August, $16^{\text {th }} 2021$

Approved:

August, $18^{\text {th }} 2021$ world of education from the PAUD/TK, SD, SLTP, SLTA to tertiary levels must take online learning to break the chain of the spread of the covid 19 virus. This research uses the method qualitative (Classroom Action Research) which refers to observations and interviews. The learning carried out for early childhood uses the Blended-Learning method which is an approach using a mixed method between face-to-face and the use of technology for distance learning. Learning using blended-learning is suitable for the development of early childhood learning because teachers can directly interact or face-to-face through online media such as videocall, zoom, and google meet. Where this learning can also increase children's enthusiasm, school from home with parental assistance. The goal is that learning can run effectively and children can understand what the teacher is saying. The results showed that children can interact well, and are enthusiastic about doing activities that will be carried out the same as in schools in general, teachers can see the active role of students in activities, the active role of parents accompanying children at home during activities, teachers can assess directly how the role of the child during the activity, whether it is capable enough or still being helped. So that an assessment is achieved according to aspects of early childhood development.

\begin{tabular}{ll}
\hline & $\begin{array}{l}\text { Luli Andriany and Rita Aryani. (2021) Implementation of Blended Learning } \\
\text { for Early Children in Kindergarten Bina Kebajika. Journal Eduvest. 1(8): 765- } \\
\end{array}$ \\
& 770 \\
How to cite: & $2775-3727$ \\
E-ISSN: & https://greenpublisher.co.id/
\end{tabular}




\begin{tabular}{ll}
\hline KEYWORDS & Learning, Early Childhood, Blended-Learning \\
\hline cc) (i) (2) & This work is licensed under a Creative Commons \\
& Attribution-ShareAlike 4.0 International License \\
\hline
\end{tabular}

\section{INTRODUCTION}

The COVID-19 pandemic has hit the whole world. Various efforts were made to break the chain of spread of the covid 19 virus (Nuraini, 2020). Covid 19 is not a disease that can be underestimated, for several reasons (Nimawati, Ruswandi, \& Erihadiana, 2020) the transmission of this covid 19 virus tends to be easily transmitted through direct contact with infected people through sneezing or coughing (Yuzar, 2020), shaking hands, and objects that are touched by people infected with the covid 19 virus. This covid 19 virus causes various complications of disease to death (Karyono, Rohadin, \& Indriyani, 2020), with symptoms that are caused, such as shortness of breath, loss of smell (Marzuki et al., 2021), loss of taste in the taste buds to shortness of breath. acute breath (Gintari, 2021). The groups that are susceptible to infection are children and the elderly over the age of 60 years (Wulandari \& Purhadi, 2020). There is no medicine that can eradicate the covid 19 virus (Darmawan, 2020), only vaccinations that have been carried out by some people (Telaumbanua, 2020), but are still at risk of contracting (Laksana \& Lestari, 2010). Continue to apply the 3 M's in daily life (Maemunawati \& Alif, 2020) (Wearing Masks, Washing Hands and Keeping Distance) and following the pattern live a healthier life by eating nutritious food, exercising diligently and getting enough rest (Yulianto, 2016).

Along with the increasingly worrying spread of Covid-19 causing various changes (Zulkarnain, Nurdin, Gojali, \& Wahyu, 2020), including in the education aspect (Daulay, 2014). The government makes various policies, one of which is issuing circulars to cancel teaching and learning activities in schools starting from the PAUD / Kindergarten level to tertiary institutions (Farid, 2020).

The recommendation to study and work from home is a special concern for every educational institution to organize effective teaching and learning activities in the midst of the current covid 19 pandemic. This sudden change in learning patterns is not easy to do, there are so many things that must be addressed starting from planning and preparing safe learning strategies so that they can produce effective processes as well as effective results to achieve learning goals. In addition, schools must also maximize existing human resources by equipping teachers with good technology skills so that learning can run well.

Learning which was originally face-to-face at school, this time must be carried out online but still must be able to bridge space and time. This problem can be done by utilizing the sophistication of digital technology. However, it is still necessary to think about how learning continues well, the need for understanding to parents in the use of digital technology as well as directions on how to use digital technology that will be used in online learning such as videocall, zoom, google meet, WA group, Classroom in accordance with the use of technology. at their respective school institutions without meeting in person.

Online learning is one type of distance learning. Simonson (2019) explains that distance learning is formal education organized by an institution or institution where teachers and students are in separate places, and uses interactive communication technology to connect students, teaching materials, and teachers. In the midst of a pandemic like this, distance education is the option chosen by almost all education actors. 
Distance learning focuses on the use and utilization of information technology with gadgets to connect students with their teachers. One of the differences in the characteristics of direct face-to-face learning is learning activities in the form of an interaction process between teachers and students. In general, there are face-to-face strategies that are teacher-centered (teacher center oriented) and student-centred learning strategies (student center oriented), while distance learning will focus on studentcentered.

One of the learning approaches that can be implemented in order to support distance learning is a blended-learning approach or a mixed approach which is an integration of face-to-face and online learning. The application of blended-learning can also improve student outcomes and satisfaction. In this case, Bina Kebajikan Kindergarten uses the Blended learning method with zoom media which can interact with students directly, and can even see directly the interaction of students with teachers and their friends. With this blended learning method, teachers can also conduct direct observations and interviews with parents and students.

Based on a questionnaire from parents about blended learning, this learning is quite effective and creates a sense of enthusiasm to be able to interact with friends, where I as a Kindergarten Bina Kebajikan teacher can make observations with 8 small kindergarten students and interview parents about learning through this method. blended learning. The results of the use of blended learning turned out to be able to make observations of the students well and maximally, so that the teacher was satisfied with the blended learning method. This method is also inseparable from the cooperation of parents in assisting children to learn from home, and good communication between teachers, students and parents.

\section{RESEARCH METHODS}

This study uses a qualitative methodology, namely classroom action which refers to observations and interviews. This research was conducted during learning during the COVID-19 pandemic at the Kindergarten of Bina Kebajikan Cibinong Gunungsindur, Bogor. Indicators and instruments were developed from the assessment of the blendedlearning environment according to (Boelens, Wever \& Voet, 2017) combined with (Ikhwan \& Widodo, 2019) and then described as an assessment rubric as a reference in determining the criteria for implementing blended-learning in PAUD/TK. Blendedlearning consists of 4 indicators namely, learning flexibility, interaction, active learning encouragement, facilitation of the learning process. The implementation of blended learning can be adjusted to each institution, which is widely used in PAUD or TK units is the Zoom application.

\section{RESULTS AND DISCUSSION}

The implementation of online learning is better known as PJJ (distance learning). PJJ is an early childhood activity that is held at home through parental assistance with children by providing remote learning by the teacher. In distance learning, the role of parents is very important so that they can provide direction to children and the reciprocal relationship between parents and children to teachers. So this also supports the jargon of the Minister of Education Nadiem Makarim "free learning" where every place is a school and everyone is a teacher.

In learning requires a process, planning, implementation, assessment and evaluation to achieve the effectiveness and efficiency of learning according to the goals that have been set at the beginning. The purpose of managing learning is time efficiency, 


\section{Luli Andriany and Rita Aryani}

as well as the effectiveness of the teaching and learning process. There are two definitions 


\section{Luli Andriany and Rita Aryani}

of blended learning that are most frequently cited in the literature, namely the theory proposed by Graham (2006), and Garisson \& Kanuka (2004), and have been cited 2149 and 3116 times, respectively (Google Scholar, October 25, 2018). Graham (2006) defines blended learning as follows: A mixed learning system combines face-to-face learning with learning using computer devices. Gorisson \& Kanuka define blended learning as a planned integration of face-to-face learning experiences with online learning.

Online learning at the PAUD/TK level is not necessarily carried out without careful planning and the stages that must be prepared, such as;

1. The preparation stage, this stage starts from checking the condition of the ability to use technology that is applied to parents. Do the parents already have an application that will be used as a distance learning medium.

2. Implementation stage, at this stage the parents convey to the child, what activities will be carried out through the tasks that have been sent by the teacher through videos or materials (theme-related pictures, videos related to the theme and so on), children are free to choose following the teacher's instructions or according to the child's own will, there is interaction, children play and documentation of activities.

3. Post-implementation stage, parents report the results of student activities by documenting children's activities, children are given the freedom to convey their work to the teacher, the teacher is obliged to answer each child's or parent's response, the teacher makes an assessment of learning \& concludes, then evaluates and follows up on the Pjj that has been done held.

In addition to the above stages, the institution also needs to provide strengthening tools by preparing the necessary supporting tools according to family conditions, such as;

a) Tools and materials according to plan

b) Narration / Explanation / Video of the steps before playing for children and the use of sharp objects that require parental assistance

c) The environment around the house

d) Tools and materials that can be used that exist in the natural environment

e) Utilization of used goods that can be used to support learning according to the learning theme

Several factors that influence the effectiveness of blended learning are experience and expertise in using the internet and several applications used in blended learning, no less important is that a strong connection (signal) is very influential.

In general, research has found that blended learning has the potential to improve the learning process, resulting in an increase in student success and satisfaction in interacting with teachers and peers online.

Based on a review from Carman, 2015 revealed that there are 5 keys to implementing blended learning such as; 1) direct or face-to-face learning, 2) independent learning, meaning that children are given the opportunity to express as they wish, 3) collaboration, collaboration between teachers and students in learning activities, 4) Assessment, teachers must be able to conclude assessments through direct interactions which is through question and answer, storytelling and the alertness of students.

\section{CONCLUSION}

In the conditions of the COVID-19 pandemic, in order to continue to be able to carry out education and carry out learning effectively, learning using blended learning is very effectively applied to early childhood. This is of course due to good communication between all parties, especially educational institutions, parents and students. However, the 


\section{Luli Andriany and Rita Aryani}

use of blended learning in PAUD/TK institutions needs to pay attention to several things, such as the concept of the digital divide where some parts of society lack digital facilities (gadgets) as well as access expansion (signals). Another important consideration in the effectiveness of blended learning is that direct interaction through online is not as much as face-to-face learning. Good cooperatiaon and communication will get results too, so that learning can be carried out properly and effectively.

\section{REFERENCES}

Darmawan, I. Putu Ariyasa. (2020). Bab 10 Eksistensi Seni Di Tengah Badai Pandemi Covid-19. Bali Vs Covid-19: Book Chapters, 151.

Daulay, Haidar Putra. (2014). Pendidikan Islam Dalam Perspektif Filsafat. Kencana.

Farid, Muhammad. (2020). Kebijakan Politik Presiden Jokowi Terhadap Masalah Kewarganeraan Dalam Merespons Isu Global: Studi Kasus Covid-19. Citizenship Jurnal Pancasila Dan Kewarganegaraan, 8(1), 1-12.

Gintari, Komang Wahyu. (2021). Gambaran Fungsi Indera Penciuman Dan Perasa Pada Pasien Covid-19 Di Ruang Jepun Rsud Bali Mandara Tahun 2021. Jurusan Keperawatan 2021.

Karyono, Karyono, Rohadin, Rohadin, \& Indriyani, Devia. (2020). Penanganan Dan Pencegahan Pandemi Wabah Virus Corona (Covid-19) Kabupaten Indramayu. Jurnal Kolaborasi Resolusi Konflik, 2(2), 164-173.

Laksana, Agung Saprasetya Dwi, \& Lestari, Diyah Woro Dwi. (2010). Faktor-Faktor Risiko Penularan Hiv/Aids Pada Laki-Laki Dengan Orientasi Seks Heteroseksual Dan Homoseksual Di Purwokerto. Mandala Of Health, 4(2), 113-123.

Maemunawati, Siti, \& Alif, Muhammad. (2020). Peran Guru, Orang Tua, Metode Dan Media Pembelajaran: Strategi Kbm Di Masa Pandemi Covid-19. 3m Media Karya.

Marzuki, Ismail, Bachtiar, Erniati, Zuhriyatun, Fitria, Purba, Agung Mahardika Venansius, Kurniasih, Hesti, Purba, Deasy Handayani, Chamidah, Dina, Jamaludin, Jamaludin, Purba, Bonaraja, \& Puspita, Ratna. (2021). Covid-19: Seribu Satu Wajah. Yayasan Kita Menulis.

Nimawati, Nimawati, Ruswandi, Uus, \& Erihadiana, Mohamad. (2020). Kajian Riset Monodisipliner Dan Interdisipliner Dalam Pendidikan Islam Menghadapi Isu Nasional Dan Global: Studi Kasus Terhadap Isu Covid-19. Misykat: Jurnal IlmuIlmu Al-Quran, Hadist, Syari'ah Dan Tarbiyah, 5(1), 101-122.

Nuraini, Siti. (2020). Penguatan Subtansi Pendidikan Agama Islam Dalam Menumbuhkan Attitude/Akhlaq Mahasiswa Di Masa Pandemi Covid 19 Di Stai Muhammadiyah Blora. Jurnal Pedagogy, 13(1), 95-112.

Telaumbanua, Dalinama. (2020). Urgensi Pembentukan Aturan Terkait Pencegahan Covid-19 Di Indonesia. Qalamuna: Jurnal Pendidikan, Sosial, Dan Agama, 12(1), 59-70.

Wulandari, Esti, \& Purhadi, Purhadi. (2020). Analisis Pengaruh Faktor-Faktor Infeksi Cacing Pada Balita Dan Anak Umur 6-12 Tahun Di Kabupaten Ende, Nusa Tenggara Timur Dengan Metode Regresi Logistik Biner. Jurnal Sains Dan Seni Its, 8(2), D185-D192.

Yulianto, Jeffri. (2016). Perilaku Sehat Pelaku Olahraga Tai Chi. Unika Soegijapranata. 
Yuzar, Dinda Nadilla. (2020). Penyakit Menular Dan Wabah Penyakit Covid-19. Osf Preprints.

Zulkarnain, Fisher, Nurdin, Ahmad Ali, Gojali, Nanang, \& Wahyu, Fitri Pebriani. (2020). Kebijakan Fatwa Mui Meliburkan Shalat Jumat Pada Masa Pandemi Covid 19. Kebijakan Fatwa Mui Meliburkan Shalat Jumat Pada Masa Pandemi Covid 19. 